\title{
Is unstable reliable? Oxygen conditions in the ecological status assessment of lakes
}

\author{
Hanna Soszka ${ }^{\star}$, Agnieszka Pasztaleniec, Agnieszka Kolada \\ Institute of Environmental Protection - National Research Institute, Kolektorska 4, 01-692 Warsaw, Poland, \\ e-mail: hasoszka@ios.edu.pl ( ${ }^{*}$ corresponding author)
}

\begin{abstract}
The Water Framework Directive introduces the requirement for ecological status assessment based primarily on aquatic organisms and supporting physico-chemical elements, including oxygen conditions. The criteria for assessing oxygen conditions applied in routine lake monitoring in Poland are based on the mean hypolimnetic saturation with oxygen at the peak of summer stagnation in stratified lakes, and on the oxygen content at the bottom in the summer in polimictic lakes. The currently used oxygen criteria usually cause dismay, particularly if biological elements indicate at least good ecological status and the oxygen conditions are the only reason for lowering status class. The aim of the article is to present the scale of variability of oxygen conditions in selected lakes within the last two decades and to analyse the limitations and conditions of applying this indicator in routine monitoring, assessment and classification of Polish lakes. Data from the years 1999-2015 on oxygen and thermal conditions in a set of nine benchmark lakes in Poland were examined and the reasons for changeability in water oxygenation from year to year were discussed. Alternative oxygen indicators were considered as well as oxygen standards based on fish protection requirements that have been adopted in some European countries. It was suggested that when assessing lake ecological status, data on the oxygen conditions from a number of years must be taken into consideration, e.g., for the analysis of trends in lake trophy changes or for documenting the effects of remedial actions in lake catchment areas in long time frames.
\end{abstract}

Key words: oxygen conditions, lake assessment, ecological status, hypolimnion oxygenation

\section{Introduction}

Measurements of temperature and oxygen content in water are by far the most frequent measurements in limnological studies. Oxygen content in lake waters is closely related to the intensity of primary production and the decomposition of organic matter. Hyperoxygenation of surface waters and reduced oxygenation of hypolimnetic waters are secondary effects of eutrophication, and oxygen content in the hypolimnion and the pace of oxygen depletion in this layer may be early symptoms of changes in lake trophy (Gibson et al. 2000). A thorough analysis of changes in oxygen concentration in Polish lakes over the past few decades (practically the second half of the 20th century) was presented by Marszelewski (2005), who found considerable reduction of oxygen concentration in most Polish lakes, especially in the hypolimnion. In the 1960s, oxygen was usually present in the entire vertical profile of lakes, including stratified ones, although its concentration at the bottom varied. At the end of the 20th century, in most dimictic lakes oxygen was absent from the bottom waters in the summer, not only at the deepest point. Currently, summer oxygen deficits often occur even at a depth of several metres. Thus, oxygen conditions well document the progress of eutrophication of Polish lakes, and may play a significant role in the assessment of changes in the quality of their waters.

The monitoring of lakes in Poland, carried out since the 1970s, has always involved the investigation of thermal and oxygen conditions. Until 2006, the strategy of monitoring had been compliant with the Lake Quality Evaluation System (LQES; Kudelska et al. 1997) and provided for two measurements a year (in the spring and at the peak of the vegetation season), including, among others, the determination of the thermal and oxygen profile at a lake's deepest points. At the time, the oxygen indicator used in the four-class classification of lake quality (three quality classes and out of class waters) involved the mean hypolimnion saturation with oxygen at the peak of summer stagnation (in stratified lakes) and oxygen content at the bottom in the summer (in non-stratified lakes). The indicators were attributed 
between 1 and 4 points (corresponding to the quality class), and the final classification of a lake was based on the mean number of points of all the indicators.

Apart from water transparency, salinity, acidity and nutrients, oxygen conditions are supporting physico-chemical elements required by the Water Framework Directive (WFD; EC 2000) in the assessment of the ecological status of lakes. Since 2007, i.e., since the moment of introducing water monitoring regulations compliant with the WFD, the frequency of examining Polish lakes has increased up to four (or six) sample collections, plus the determination of the thermal and oxygen profile at the deepest point of a lake on each sampling occasion (ME 2013). The WFD introduces the requirement to assess the ecological status of waters based mainly on socalled biological elements, i.e., groups of aquatic organisms (phytoplankton, macrophytes and phytobenthos, benthic macroinvertebrates and fish). In accordance with the WFD and the guidelines for ecological status classification (CIS-WFD 2003b), supporting physicochemical elements are taken into consideration when assessing water body status as high or good. The criteria for assessing oxygen conditions applied in Poland since 2008 in routine lake monitoring are based, just as in the case of the LQES, on the mean hypolimnetic saturation with oxygen at the peak of summer stagnation in stratified lakes, and on the oxygen content at the bottom in the summer in polimictic lakes (ME 2014). For these indicators, threshold values have only been established for good/moderate ecological status boundary and these were set at $10 \%$ of hypolimnion oxygen saturation and $4 \mathrm{mg} \mathrm{O}_{2} \mathrm{dm}^{-3}$, respectively. While in the LQES the final assessment of water quality was based on the average number of points assigned to individual indicators, in the case of assessment pursuant to the WFD we apply the one-out-all-out (OOAO) principle: the final classification results from the biological element which indicates the poorest condition. The ecological status can only be rated as at least good if the supporting physicalchemical elements (including oxygen conditions) meet the criteria for good quality.

When applying the OOAO principle, the current oxygen criteria used in lake classification usually cause dismay, particularly if biological elements indicate at least good ecological status but the oxygen conditions are the only reason for lowering status class. Such a situation happens very often in Polish lakes (reports on results of lake monitoring to be found at www.gios. gov.pl). Thus, the question arises as to whether current oxygen criteria can be considered supporting for biological elements in ecological status assessment. To disentangle this problem, we examined a long-term series of data on oxygen and thermal conditions in a set of benchmark lakes in Poland.
Lake monitoring in Poland involves an annual survey of 22 benchmark lakes (ME 2013). They represent the full spectrum of ecological status classes. They are surveyed by Voivodship Inspectorates of Environmental Protection in accordance with the schedule of the State Environmental Monitoring established by the Chief Inspectorate of Environmental Protection, six times a year between spring and autumn. The objective is to evaluate long-term changes in natural conditions and those resulting from widespread anthropogenic activity.

The aim of the article is to present the scale of variability of oxygen conditions in selected benchmark lakes within the last two decades and to analyse the limitations and conditions of applying this indicator in routine monitoring, assessment and classification of Polish lakes.

\section{Material and methods}

Out of all 22 benchmark lakes in Poland, nine lakes were selected for analyses, for which data (including data on oxygen conditions) from the years 19992015 are available. For the other benchmark lakes, since series are much shorter and only cover the period from 2008. The seventeen-year data series refer to eight stratified lakes and one polimictic lake (Fig. 1, Table 1).

Measurements of temperature and oxygen in the vertical profile of lakes were made at the lakes' deepest points, at a 1-metre interval, using a dissolved oxygen probe. In stratified lakes, the range of each thermal layer was estimated based on the thermal profile at the peak

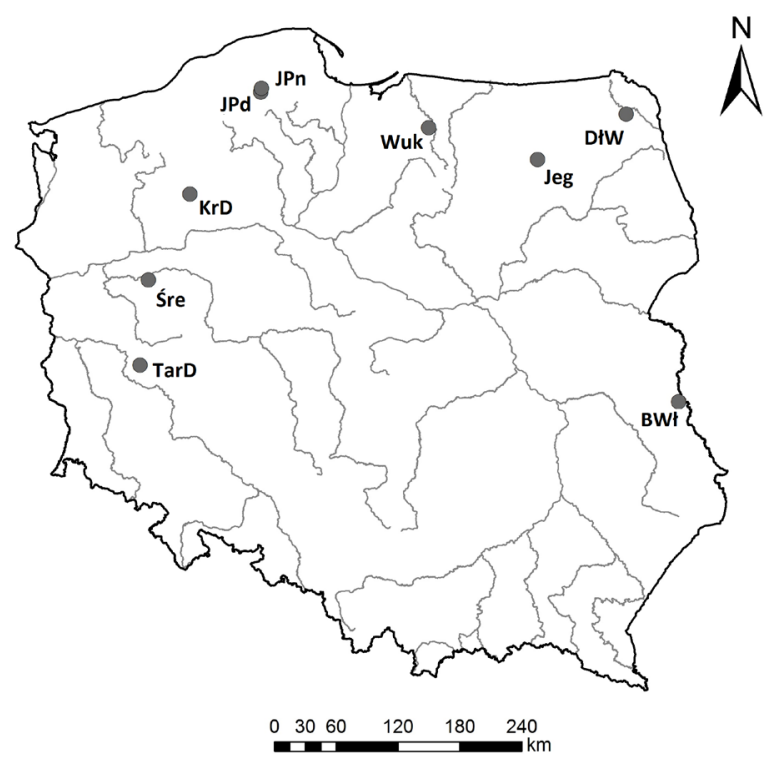

Fig. 1. Location of the analysed benchmark lakes in Poland. Key to lake name abbreviations is given in Table 1 
Table 1. Characteristics of nine benchmark lakes under study, Abb. - lake name abbreviation, A - surface area (ha), $z_{\text {max }}$ - maximum depth $(\mathrm{m}), \mathrm{z}_{\text {mean }}$ - mean depth (m), \% hypo - range (min-max) of the share of hypolimnion in total water volume in the years 19992015, Chla - range ( $\min -\max$ ) of the seasonal means of chlorophyll $a$ concentrations in the years $1999-2015\left(\mu \mathrm{g} \mathrm{dm}{ }^{-3}\right)$; na - not applicable

\begin{tabular}{lcccccc}
\hline \multicolumn{1}{c}{ Lake name } & Abb. & $\mathrm{A}$ & $\mathrm{z}_{\max }$ & $\mathrm{z}_{\text {mean }}$ & $\%$ hypo & Chla \\
\hline \multicolumn{7}{c}{ Stratified lakes } \\
\hline Śremskie & Śre & 115.8 & 45.0 & 20.7 & $52-63$ & $3.0-16.5$ \\
\hline Krąpsko Długie & $\mathrm{KrD}$ & 73.9 & 15.1 & 7.6 & $9-21$ & $4.0-13.5$ \\
\hline Jasień Południowy & $\mathrm{JPd}$ & 346.9 & 22.6 & 7.5 & $6-26$ & $5.7-30.0$ \\
\hline Jasień Północny & $\mathrm{JPn}$ & 241.6 & 32.2 & 9.1 & $10-24$ & $3.9-15.1$ \\
\hline Jegocin & $\mathrm{Jeg}$ & 127.4 & 36.1 & 9.0 & $22-30$ & $1.7-3.9$ \\
\hline Wukśniki & Wuk & 117.1 & 68.0 & 23.4 & $64-72$ & $4.1-10.3$ \\
\hline Długie Wigierskie & DłW & 80.0 & 14.8 & 7.4 & $14-21$ & $1.9-15.4$ \\
\hline Białe Włodawskie & BWł & 106.4 & 33.6 & 14.1 & $40-49$ & $2.5-9.7$ \\
\hline \multicolumn{7}{c}{ Polymictic lake } \\
\hline Tarnowskie Duże & TarD & 91.6 & 7.5 & 3.8 & na & $8.1-22.6$ \\
\hline \multicolumn{7}{c}{}
\end{tabular}

of summer stagnation; the mean temperature and oxygen saturation of the hypolimnion as well as the thermal gradient in the metalimnion were calculated. In the polimictic lake, water temperature and oxygenation at the bottom were studied. The variability of temperature and oxygen content between the surface and bottom layers was also analysed with regard to the whole vegetation season and the summer months (June-August).

The analysis of thermal and oxygen conditions was performed against the background of changes in chlorophyll $a$ concentration. This indicator was routinely measured over the discussed seventeen-year period. Actually, in the years 1999-2006, it was the only biological element applied in lake assessment. The temporal variation of the considered indicators was presented using a coefficient of variation (cv), which is the ratio of the standard deviation and the arithmetic mean (expressed as a percentage). The non-parametric Mann-Kendall $(\mathrm{M}-\mathrm{K})$ test was used to determine the significance of tendencies of oxygen conditions and chlorophyll $a$ concentration changes in a time-series. The XLSTAT statistical package (Addinsoft 2013) was used for the calculations.

\section{Results}

The analysis of spring thermal and oxygen profiles shows that waters in the discussed lakes were often not fully mixed, and the difference in temperature and oxygen concentrations between the surface and bottom layers were several degrees and several milligrams of $\mathrm{O}_{2}$ per litre. Hypolimnion saturation with oxygen in the examined stratified reservoirs changed distinctly from year to year (Fig. 2), with the exception of lakes Jasien Północny and Jasien Południowy, where the hypolim- nion was constantly deoxygenated at the peak of the summer stagnation. Thus, oxygen conditions of these two lakes did not meet the criterion for good status in the analysed seventeen-year period. As for the other lakes, cases of complete deoxygenation of the hypolimnion in the summer occurred in Lake Długie Wigierskie in the years 2004-2008 (Fig. 2). Oxygen saturation of the waters of this lake was $11 \%$ as a maximum, and it often decreased below $2 \%$. Hence, the criterion for good status in terms of oxygen conditions was not met in this lake for most of the time. On the other hand, high oxygen content in the hypolimnion (even 60\%) was observed in the deepest of the analysed reservoirs, Lake Wukśniki. It met the criterion for good status over the analysed period. In two other deep lakes, Śremskie and Białe Włodawskie, hypolimnion saturation with oxygen was very changeable, and in some years of the study, it decreased below $10 \%$, which at that time meant a failure to meet the criterion for good status. Jegocin and Krąpsko Długie are lakes where the highest saturation of hypolimnion with oxygen was approximately $20 \%$, but values below $10 \%$ were also often observed.

Low mean water temperatures were typical of the vast hypolimnions of three deep lakes with the best oxygen conditions and a smaller hypolimnion of Lake Jegocin with poorer oxygen conditions (Fig. 3a, b). The other lakes with much smaller hypolimnions had a higher mean temperature of hypolimnetic waters, from 6.7 (Jasień Północny) up to $8.6^{\circ} \mathrm{C}$ (Jasień Południowy). The steepest thermal gradient in the metalimnion (the mean value of nearly $3.0^{\circ} \mathrm{C} \mathrm{m}^{-1}$ in the analysed period) occurred in Lake Wukśniki, and the mildest, in Jasień Południowy and Jasień Północny $\left(2.0^{\circ} \mathrm{C} \mathrm{m}^{-1}\right.$ on average; Fig. 3c). The thermal gradient in the metalimnion of the other lakes, although greatly variable from year to year, had a mean value of over $2.5^{\circ} \mathrm{C} \mathrm{m}^{-1}$ (Fig. 3c).

The coefficient of variation $(\mathrm{CV})$ of hypolimnion saturation with oxygen in the analysed lakes (except lakes Jasień Północny and Jasień Południowy, where the hypolimnion was practically deoxygenated in all the years under consideration) greatly varied but was usually high (Table 2). It was the highest in Lake Długie Wigierskie (132\%), and the lowest in Lake Wukśniki $(28 \%)$. The analysis of trends of long-term changes revealed deteriorating oxygen conditions in the hypolimnions of all the studied lakes (except Jasień Północny and Jasień Południowy) within the past 17 years (a negative trend), but it was statistically significant $(\mathrm{p}<0.05)$ only in the case of lakes Śremskie and Krąpsko Długie (Table 2).

In the years 1999-2015, in the one considered polimictic Lake, Tarnowskie Duże, the oxygen content exceeded $4 \mathrm{mg} \mathrm{O}_{2} \mathrm{dm}^{-3}$ in the entire water column in the spring (March-May) and in the fall (September- 

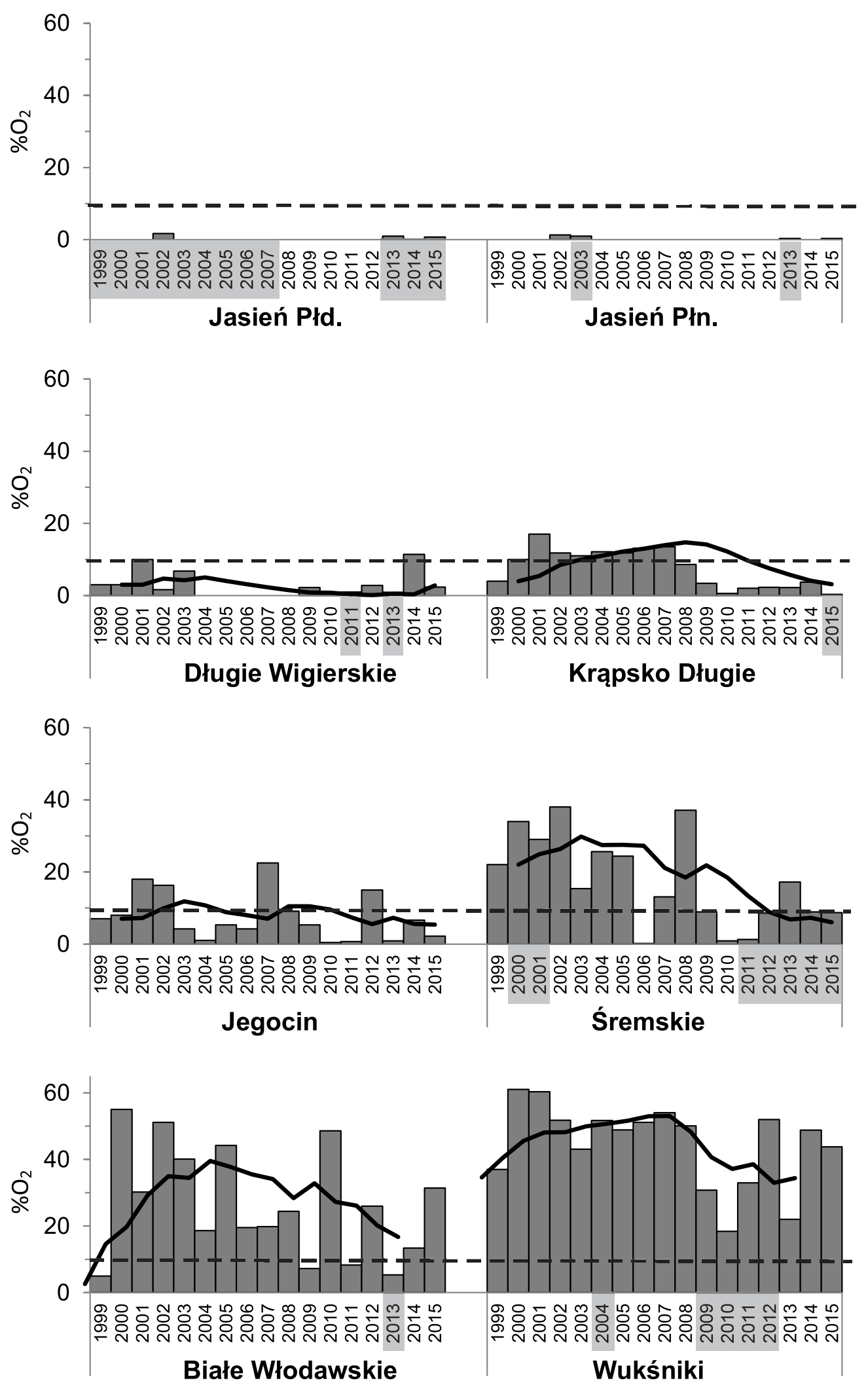

Fig. 2. Changes in oxygen saturation of hypolimnion $\left(\% \mathrm{O}_{2}\right)$ in eight benchmark lakes in Poland. Solid lines indicate trends based on the Mann-Kendall's test. Dashed lines indicate the boundary value for good/moderate ecological status (ME 2014). Shaded areas indicate years when a lake was assessed as less than good based on the type-specific criteria for chlorophyll a concentration (ME 2014) 
October), although occasionally in some years the spring oxygen content at the bottom was much lower than on the surface (even by as much as $8 \mathrm{mg} \mathrm{O}_{2} \mathrm{dm}^{-3}$ as in April 2010). In such cases, the temperature of water at the bottom was lower than on the surface by sev-
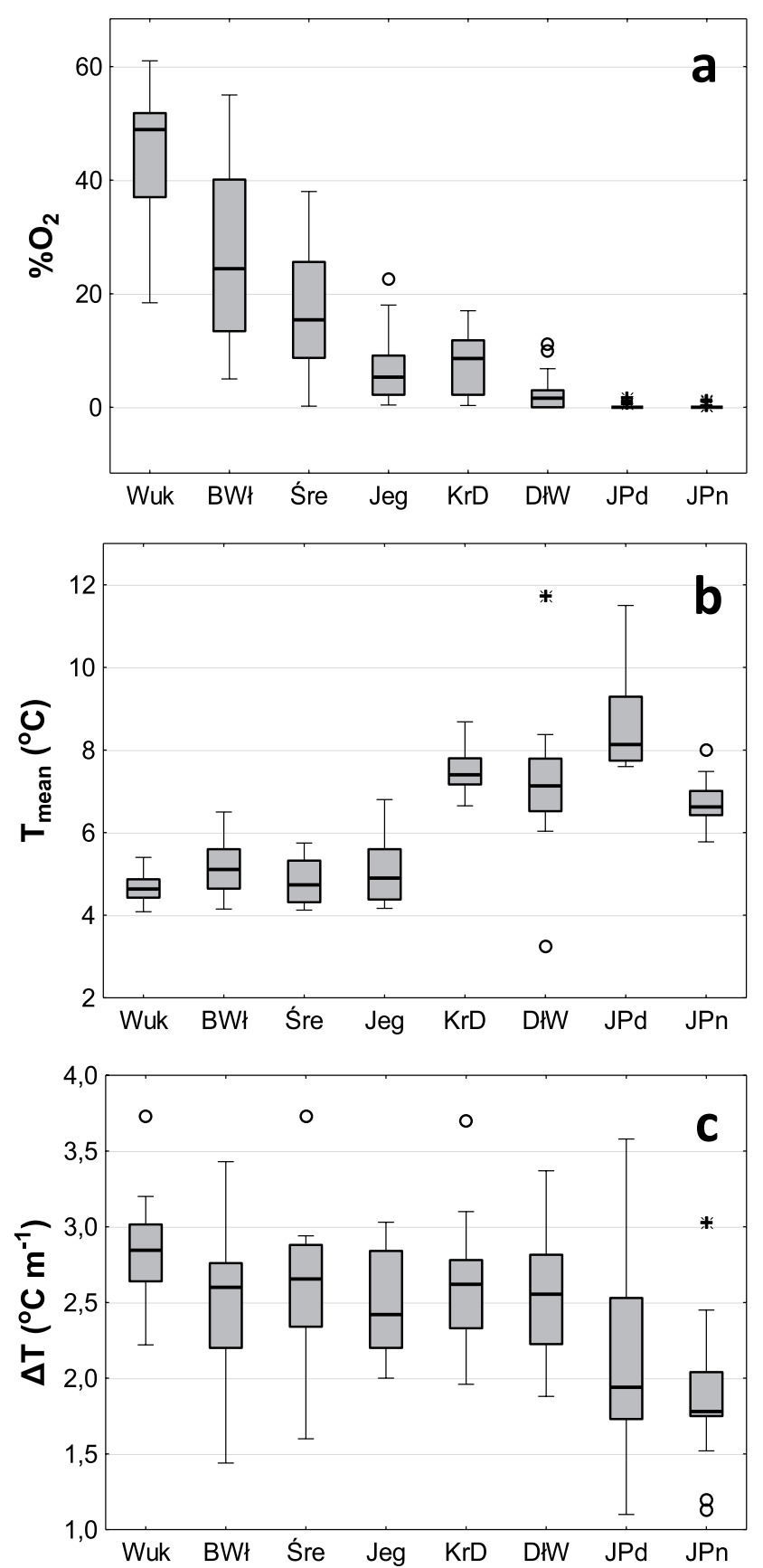

Fig. 3. Distribution of oxygen saturation of hypolimnion $\left(\% \mathrm{O}_{2}\right)$ [a], mean temperature of hypolimnion $\left(\mathrm{T}_{\text {mean }}\right)[\mathrm{b}]$ and metalimnetic thermal gradient $(\Delta \mathrm{T})[\mathrm{c}]$ in eight benchmark lakes in Poland. The whisker-plots present quartile range with median (vertical lines), non-outlier range (whiskers), outlying (circles) and extreme values (stars). Key to lake name abbreviations is given in Table 1
Table 2. The variability coefficients (cv) and the results of the MannKendall test (tau and two-tailed p-value) based on the oxygen saturation of hypolimnion in summer $\left(\% \mathrm{O}_{2}\right)$ and seasonal mean of chlorophyll $a$ concentration (Chla) in stratified benchmark lakes analysed in the years 1999-2015; trends statistically significant at $\mathrm{p}<0.05$ are marked in bold; na - not applicable

\begin{tabular}{lccccrc}
\hline \multirow{2}{*}{ Lake } & \multicolumn{3}{c}{$\% \mathrm{O}_{2}$} & \multicolumn{3}{c}{ Chla } \\
\cline { 2 - 7 } & $\mathrm{cv}$ & $\mathrm{M}-\mathrm{K}$ tau & $\mathrm{M}-\mathrm{K} \mathrm{p}$ & $\mathrm{cv}$ & $\mathrm{M}-\mathrm{K}$ tau & $\mathrm{M}-\mathrm{K} \mathrm{p}$ \\
\hline Wukśniki & 28 & -0.34 & 0.063 & 28 & 0.24 & 0.205 \\
\hline Białe Włodawskie & 63 & -0.19 & 0.308 & 38 & -0.10 & 0.621 \\
\hline Śremskie & 73 & $-\mathbf{0 . 4 1}$ & 0.026 & 47 & 0.31 & 0.105 \\
\hline Jegocin & 90 & -0.25 & 0.173 & 23 & 0.32 & 0.083 \\
\hline Krąpsko Długie & 72 & $-\mathbf{0 . 4 4}$ & 0.017 & 30 & 0.31 & 0.091 \\
\hline Długie Wigierskie & 132 & -0.01 & 1.000 & 69 & $\mathbf{0 . 5 4}$ & 0.002 \\
\hline Jasień Południowy & na & na & na & 52 & -0.15 & 0.440 \\
\hline Jasień Północny & na & na & na & 40 & -0.29 & 0.109 \\
\hline \multicolumn{7}{c}{ Polymictic lake } \\
\hline Tarnowskie Duże & na & na & na & 28 & -0.04 & 0.867 \\
\hline \multicolumn{7}{c}{}
\end{tabular}

eral degrees Celsius (Fig. 4). Between June and August, oxygen content at the bottom was usually low (below $4 \mathrm{mg} \mathrm{O} \mathrm{dm}^{-3}$ ), or even at the trace level, although in some years the lake waters had a homogenous temperature and good oxygenation from the surface to the bottom (August 1999 and 2000, and July 2013). Low oxygen contents at the bottom observed in the summer and spring were accompanied by a considerable difference between the temperature of surface and bottom waters, in most cases reaching at least $3^{\circ} \mathrm{C}$ (Fig. 4).

Changes of chlorophyll $a$ contents in the epilimnion, observed simultaneously in the years 1999-2015, showed a much smaller range of $\mathrm{cv}$ values than in the case of the hypolimnion oxygenation (Table 2). The co-

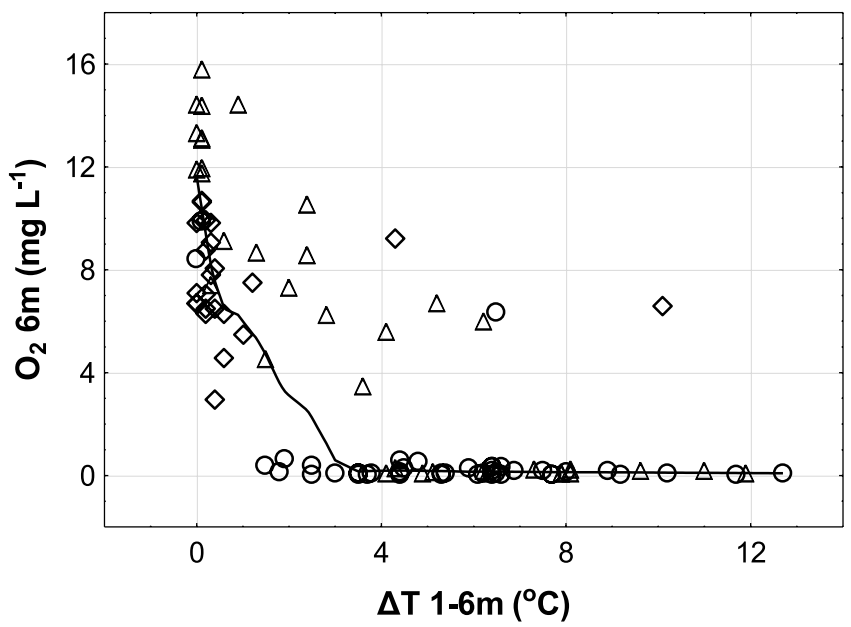

Fig. 4. The relationship between the differences in temperature between 1 and $6 \mathrm{~m}$ depth $(\Delta \mathrm{T} 1-6 \mathrm{~m})$ and the oxygen concentration at the depth of $6 \mathrm{~m}$ (bottom layer; $\mathrm{O}_{2} 6 \mathrm{~m}$ ) in Lake Tarnowskie in the period 1998-2015. Symbols indicate samples from different seasons: spring (triangles), summer (circles) and autumn (diamonds) 
efficient was between 23\% in Lake Jegocin and 69\% in Lake Długie Wigierskie. Moreover, an increasing trend of chlorophyll $a$ content was found in five lakes, and a decreasing one, in four lakes. Only in Lake Długie Wigierskie was the increase of chlorophyll $a$ statistically significant, although even there it was not accompanied by a statistically significant deterioration of oxygen conditions (Table 2). No relationship was found between hypolimnion oxygenation and chlorophyll $a$ content with reference to a lake-specific boundary value for good or high status (Fig. 2). For example, chlorophyll a concentrations in Lake Jegocin, corresponding to at least good status in the whole period under consideration, in $80 \%$ were accompanied by hypolimnion oxygen contents lower than $10 \%$. This was also the case in the other stratified lakes in some years of the research. The opposite often occurs as well. Chlorophyll $a$ concentrations corresponding to an ecological status poorer than good are accompanied by high hypolimnion oxygenation, sufficient to meet the criterion for good status (Lake Śremskie - years 2000, 2001, 2013, Lake Wukśniki - years 2004, 2009-2012). Neither correlation between oxygen content at the bottom and chlorophyll $a$ concentration in polimictic Lake Tarnowskie Duże was found. Mean chlorophyll concentrations in individual years of the study period did not exceed the type-specific values, corresponding to at least good status $\left(<23 \mu \mathrm{g} \mathrm{dm}^{-3}\right.$; Table 1$)$, whereas oxygen content usually did not meet the criterion for good (at least $4 \mathrm{mgO}_{2} \mathrm{dm}^{-3}$; Fig. 4).

\section{Discussion}

Why the currently used oxygen criteria are of a limited applicability for lake assessment?

The presented results indicate the relatively high variability of oxygen conditions from year to year in the analysed benchmark lakes, with the exception of lakes Jasień Północny and Jasień Południowy, which had deoxygenated hypolimnions throughout the seventeenyear period. The content of chlorophyll $a$, being the measure of phytoplankton abundance, remained relatively low, in most lakes corresponding to at least good ecological status, and was not related to changes in water oxygenation (Fig. 2). It is worth adding that since 2011, the multimetric Phytoplankton Metric for Polish Lakes (PMPL) (Hutorowicz and Pasztaleniec 2014), consisting of three metrics (chlorophyll $a$ concentration, total biomass, and Cyanoprocaryota biomass) has been the basis for ecological status evaluation, in place of only chlorophyll $a$ concentration applied before. Assessment based on phytoplankton (using the PMPL) reveals at least good ecological status of most of the studied lakes, generally unchanged in recent years (reports to be found at www.gios.gov.pl). Only in Lake Jasień Południowy, has phytoplankton recently demonstrated a moderate ecological status, just as in the case of Długie Wigierskie and Białe Włodawskie in single years of study beginning with 2011. Therefore, the reasons for variability in water oxygenation from year to year should be first of all considered against natural factors, not as the indicator of increasing of primary production intensity.

Summer thermal and oxygen relationships are greatly affected by weather conditions changing from year to year (Korycka 1969; Zachwieja 1975), and first of all, by the intensity of spring water mixing. If the mixing is not complete, as a result of rapid air and surface water layers warming and early thermal stratification, lakes enter the vegetation season with little oxygen supply in the hypolimnion, which soon becomes insufficient (Patalas 1960; Livingstone and Imboden 1996; Kajak 1998). This occurred many times in the analysed lakes. Out of the eight studied stratified lakes, the highest hypolimnion oxygenation was in the deepest lakes with vast hypolimnions: Śremskie, Wukśniki, and Białe Włodawskie. However, even in this group there were cases of low oxygenation or even complete deoxygenation of hypolimnion at the peak of summer stagnation. This occurred in the years when spring circulation was probably short, without complete homothermy and homooxygeny. Thus, the oxygen supply accumulated in the spring was lower than in the years with full spring water circulation, and led to the low summer oxygen content in the hypolimnion. Similarly, in shallower lakes such as Długie Wigierskie, Jegocin, or Krąpsko Długie, the water was often not completely mixed in the spring which affected summer hypolimnion oxygenation. Besides, in these lakes, hypolimnion constitutes a small proportion of the lake volume (Table 1). In such a situation, the inflow of matter from the trophogenic to the tropholytic zone exceeds the capacity of its decomposition and quickly leads to oxygen depletion in the hypolimnion, even in lakes with lower productivity (Patalas 1960; Vollenweider and Janus 1982). Furthermore, the above-mentioned group of shallower lakes, as well as the deeper Lake Jasien Północny, have warmer hypolimnions (Fig. 3b) than the other stratified lakes. Higher water temperature increases the rate of decomposition processes in the hypolimnions (Vollenweider and Janus 1982) and is an additional factor explaining poorer oxygen conditions in these lakes compared to lakes with cold hypolimnions.

Two lakes with constantly deoxygenated hypolimnions (Jasień Północny and Jasień Południowy) differed from the others with quite mild thermal gradients in the metalimnion (Fig. 3c). It was the steepest in Lake Wukśniki, which displayed good oxygenation of 
the hypolimnion in the whole seventeen-year period. A steep thermal gradient in the metalimnion retains the falling organic matter and limits its transition to the hypolimnion (Gliwicz 1979). This mechanism could cause lower oxygen consumption in the hypolimnion of Lake Wukśniki and higher concentrations of this gas in comparison to the other lakes.

Periodical oxygen deficits at the bottom in shallow, non-permanently stratified Polish lakes were reported by Radwan et al. (1973) and Olszewski and Paschalski (1959). They are caused by temporary water stagnation alternating with temporary water movements, both of which may prevail. The periods of stagnation can be accompanied by reduced oxygen content at the bottom. This is the case in Lake Tarnowskie Duże. A considerable difference in temperature between surface and bottom waters (by several degrees), which is often observed in the summer, testifies to long periods of lake water stagnation accompanied by a decrease of oxygenation at the bottom. Hence, oxygen content in water depends on many natural factors and is subject to huge fluctuations, and the observed oxygen deficits in bottom waters may be natural, i.e., they may occur both in lakes with an undisturbed status of biological elements and in lakes with an ecological status worse than good.

Huge natural variability of oxygen conditions undermines the applicability of the simple form of this indicator in assessment (as oxygen content/saturation). According to the WFD (Annex II, 1.3), an element with high natural variability (not resulting from natural seasonal changes) may be excluded from the ecological status assessment for the given category of surface waters. The basic property of an indicator used to assess the ecological status is its low natural variability and the reference values of the indicator must have a sufficient level of confidence to provide reliable classification (CIS-WFD 2003a). In the case of the oxygen indicator, it seems hardly possible to establish a reliable reference value for oxygen concentration or water oxygen saturation even if the site-specific conditions (inherent for the given lake) are considered. Perhaps then, an alternative is to find an appropriate oxygen indicator to assess the ecological status of lakes other than the currently applied hypolimnion oxygen saturation or absolute summer oxygen content at the bottom in polimictic lakes.

\section{Which oxygen indicators can offer an alternative to those currently used in lake assessment?}

The rate of oxygen consumption in the hypolimnion has been considered a reliable indicator of lake productivity and trophy for a hundred years (Borowiak et al. 2011). Oxygen depletion in this layer can be characterised in several ways, e.g., as an areal hypolimnetic oxygen deficit (AHOD), i.e. the mean oxygen depletion under one square centimetre of hypolimnion surface per time unit (e.g., 1 day) between the end of spring circulation and the peak of summer stagnation. However, AHOD is not always correlated to lake productivity or nutrient content. In five dimictic lakes in northern Poland, Borowiak et al. (2011) demonstrated a strong relationship between AHOD and Carlson's trophic state index (TSI) calculated based on the chlorophyll $a$ but a very weak relationship between AHOD and TSI calculated based on the water transparency and phosphorus content. Cornett and Rigler (1980) found a positive relationship between AHOD and total phosphorus content and primary production, and a negative one between AHOD and Secchi disk visibility. Those correlations, however, were weak, which is related to the mean depth and water temperature of the hypolimnion. Walker (1979) found a strong relationship between AHOD and TSI in 30 American lakes when he incorporated the mean depth into the model. Oxygen depletion in the hypolimnion is also associated with the dynamics of hypolimnetic waters independent of the eutrophication process (Edwards et al. 2005). Although boundary values of AHOD for lakes with different levels of trophy are presented in literature, they are rather approximate and charged with considerable uncertainty (Wetzel 2001). Apart from the influence of lake morphometry and hypolimnetic water temperature on oxygen conditions in the hypolimnion, this uncertainty may also result from a steep thermal gradient in the metalimnion. When the gradient is steep, a lot of organic matter is decomposed in the epilimnion and it never reaches the hypolimnion, and thus the AHOD is underestimated. In lakes with high water transparency, where primary production occurs in the metalimnion or even the upper part of the hypolimnion, estimation of the rate of oxygen depletion in the hypolimnion may be obscured by photosynthesis, which provides oxygen, as well as by the influx of river waters, rich in oxygen and organic matter. When the oxygen concentration is lower than $2 \mathrm{mg} \mathrm{O}_{2} \mathrm{dm}^{-3}$, its depletion is slower and this indicator becomes unreliable (Wetzel 2001).

The usability of an indicator in routine monitoring is substantially affected by practical factors, such as the required frequency of field measurements. The minimum frequency of thermal and oxygen measurements depends on the rate of oxygen consumption in the hypolimnion, which, as mentioned above, is affected by the volume of the hypolimnion and the temperature of its waters, as well as the amount of organic matter reaching the hypolimnion. Sometimes this minimum frequency of measurements is one month, and sometimes it is not more than a few hours (Gibson et al. 2000). Thus, AHOD cannot be effectively applied in 
the assessment of lakes in which the hypolimnion becomes anaerobic at the beginning of or during the summer stagnation. In practice, it can only be used in the assessment of oxygen conditions of dimictic, deep and large lakes with low or moderate productivity, with low supply of allochtonic organic matter. This means that AHOD may have limited usability in the monitoring of Polish lakes, most of which are eutrophic.

The routine monitoring of Polish lakes basically involves four measurements of thermal and oxygen conditions, the first of which should be performed during the spring circulation, the next two at the beginning of summer stagnation (June) and at the peak of summer stagnation (August). The last measurement is performed during the fall circulation. In the case of benchmark lakes, measurements are performed six times a year during the vegetation season in monthly intervals. In most Polish lakes, oxygen deficits in the bottom water layers occur even in June, and they very quickly spread to the whole hypolimnion. Hence, very often the study of the thermal and oxygen profile in the summer takes place too late to analyse the speed of oxygen depletion, for nobody knows how long there has been a shortage of oxygen. For the same reason, in routine monitoring it is hard to follow the approach of Nürnberg (1995), who proposes to use the anoxic factor (AF) in the assessment of oxygen conditions in the hypolimnions of stratified lakes. The anoxic factor is the number of days in a year or in the summer season when bottom sediments contact deoxygenated waters. The lake surface area is taken into account when calculating the value of the factor which ensures its comparability among lakes. AF can be calculated not only on the basis of direct measurements of the thermal and oxygen profile but it can also be forecast using regression models based on nutrient concentration and lake morphometry, as well as redox potential and Fe concentration. For Polish lakes, such models do not exist, so it is hard to speculate the possibility of applying such a method in routine monitoring.

Approaches to oxygen condition assessment applied in other EU Member States

According to the WFD, the supporting physicochemical elements in high and good status should ensure the achievement of a high or good status of biological elements. The majority of the biota, which provide the basis for an assessment of the ecological status of lakes (phytoplankton, littoral zoobenthos, phytobenthos or macrophytes) can be found in shallow lake zones or epilimnion which, in general, are characterised by high oxygen content irrespective of the degree of water eutrophication. Fish inhabit all the lake zones and can respond to oxygen depletion in deeper waters.
Therefore, the oxygen criteria for the ecological status assessment of lakes should refer to the requirements of ichthyofauna. Some countries have adopted standards for an oxygen indicator based on fish protection requirements laid down in the Directive on the quality of fresh waters needing protection or improvement in order to support fish life (EC 2006). The directive distinguishes only two types of waters, salmonid and cyprinid waters. In the UK, salmonid oxygen standards are assigned to stratified lakes and refer to the mean oxygen content below the thermocline in the peak of summer stagnation while cyprinid standards are adopted for non-stratified lakes and refer to the mean dissolved oxygen value in the entire water column. The boundary values, regardless of lake mixing type, for high and good status for salmonids are, respectively, 9.0 and $7.0 \mathrm{mg} \mathrm{O}_{2} \mathrm{dm}^{-3}$, while those for cyprinids are 8.0 and $6.0 \mathrm{mg} \mathrm{O}_{2} \mathrm{dm}^{-3}$ (DEFRA 2015). Similarly, in Norway, preliminary oxygen threshold values for five classes of lake ecological status are based on the tolerance of fish towards oxygen deficits (Direktoratsgruppa 2013). For clear water lakes (inhabited by salmonids) and humic lakes (inhabited by cyprinids) standard values are set as a $50^{\text {th }}$ and $5^{\text {th }}$ percentile. For high/good ecological status, boundary oxygen concentrations are 12 and $9 \mathrm{mg} \mathrm{O}_{2} \mathrm{dm}^{-3}$, respectively, in salmonid lakes, and 9 and $5 \mathrm{mg} \mathrm{O}_{2} \mathrm{dm}^{-3}$, respectively, in cyprinid lakes. For good/moderate status, boundary oxygen concentrations are 9 and $5 \mathrm{mg} \mathrm{O}_{2} \mathrm{dm}^{-3}$, respectively, in salmonid lakes, and 5 and $2 \mathrm{mg} \mathrm{O}_{2} \mathrm{dm}^{-3}$, respectively, in cyprinid lakes. These values are relevant for hypolimnion in stratified lakes and for the entire water column in polymictic lakes. In Sweden, oxygen based criteria refer to lakes inhabited by "common" warmwater fish and by mostly salmonids and are set for the period of homothermy (SEPA 2010). The boundary value for high ecological status class for the two types of lakes is 8 or $7 \mathrm{mg} \mathrm{O}_{2} \mathrm{dm}^{-3}$, respectively. The oxygen standard for good ecological status class additionally includes water temperature. If it exceeds $15^{\circ} \mathrm{C}$, minimum oxygen concentration should reach more than 5 or $6 \mathrm{mg} \mathrm{O}_{2} \mathrm{dm}^{-3}$, respectively. In colder waters, oxygen content should be higher. If the observed concentration of oxygen indicates high or good status, this will be the final classification. If it indicates worse status class, one should decide if it is natural or the result of anthropogenic impact by calculating a reference value. A precise, rather demanding calculation procedure and interpretation of the results are given. A different approach towards setting oxygen criteria for lake assessment has been adopted in Austria. Oxygen criteria are type-specific or site-specific, for selected lakes (mainly alpine or subalpine), and refer to hypolimnion saturation with oxygen (30-70\%) (BMLFUW 2010). In France, only an approximate value 
of good/moderate status class boundary was elaborated for stratified lakes. It refers to oxygen deficit observed in hypolimnion in relation to surface waters' oxygenation and it is 50\% (MEEM 2016).

The presented criteria and approaches to assessing oxygen conditions of lakes in European countries cannot be applied to ecological status assessment of Polish lowland lakes because they cannot solve the problem of discrepancy between biological classification and classification based on oxygen conditions in lakes with a good status of biological elements. In this situation, it is worth assuming that in order to include this indicator in assessing lake ecological status data from a number of years must be taken into consideration, e.g., for the analysis of trends in lake trophy changes or for documenting the effects of remedial actions in lake catchment areas in long time frames.

\section{Acknowledgements}

The Chief Inspectorate for Environmental Protection and voivodeship inspectorates for environmental protection in Poland are kindly acknowledged as the providers of biological and water physichochemical data obtained within the framework of state environmental monitoring used in this study. Special thanks go to our Colleague, Sebastian Kutyła, who supported us in preparing the Figure 1.

\section{References}

Addinsoft, 2013, XLSTAT [Computer Software], New York, New York. Retrieved from http://www.xlstat.com/.

BMLFUW [Bundesministers für Land- und Forstwirtschaft, Umwelt und Wasserwirtschaft], 2010, 99. Verordnung des Bundesministers für Land- und Forstwirtschaft, Umwelt und Wasserwirtschaft über die Festlegung des ökologischen Zustandes für Oberflächengewässer (Qualitätszielverordnung Ökologie Oberflächengewässer - QZV Ökologie OG). Bundesgesetzblatt für die Republik Österreich, am 29 März 2010, Teil II, [CELEX-Nr.: 32000L0060].

Borowiak D., Nowiński K., Barańczuk J., Marszelewski W., Skowron R., Solarczyk A., 2011, Relationship between areal hypolimnetic oxygen depletion rate and the trophic state of five lakes in northern Poland, Limnol. Rev. 11(4): 135-142.

[CIS-WFD] Common Implementation Strategy - Water Framework Directive, 2003a, Guidance on establishing reference conditions and ecological status classes boundaries for inland surface waters, Guidance document of Working Group 2.3 Reference conditions for inland surface waters (REFCOND), $86 \mathrm{pp}$.

[CIS-WFD] Common Implementation Strategy - Water Framework Directive, 2003b, Overall Approach to the Classification of Ecological Status and Ecological Poten- tial, Guidance document of Working Group 2A Ecological Status (ECOSTAT), 53 pp.

Cornett R.J., Rigler F.H., 1980, The areal hypolimnetic oxygen deficit: An empirical test of the model, Limnol. Oceanogr. 25: 672-679.

[DEFRA] Department for Environment, Food and Rural Affairs, 2015, 2010 to 2015 government policy: water quality [updated 8 May 2015], Environment Agency, Office for Water Services. Retrieved from https://www.gov.uk/ government/publications/2010-to-2015-governmentpolicy-water-quality.

Direktoratsgruppa, 2013,Veileder 02:2013. Klassifisering av miljøtilstand i vann. Økologisk og kjemisk klassifiseringssystem for kystvann, grunnvann, innsjøer og elver, Direktoratsgruppa for gjennomføring av vanndirektivet, 263 pp. (in Norwegian).

[EC] European Commission, 2000, Directive 2000/60/EC of the European Parliament and of the Council of 23 October 2000 establishing a framework for Community action in the field of water policy, Offic. J. Eur. Union L327 43: $1-72$.

[EC] European Commission, 2006, Directive 2006/44/EC of the European Parliament and of the Council of 6 September 2006 on the quality of fresh waters needing protection or improvement in order to support fish life, OJEU L 264 49: $20-31$.

Edwards W.J., Conroy J.D., Culver D.A., 2005, Hypolimnetic oxygen depletion dynamics in the central basin of Lake Erie, J. Great Lakes Res. 31(2): 262-271.

Gibson G., Carlson R., Simpson J., Smeltzer E., Gerritson J., Chapra S.H., Jones J., Kennedy R., 2000, Nutrient criteria technical guidance manual: Lakes and reservoirs, US EPA-822-B00-001, Office of Water. Office of Science and Technology, Washington.

Gliwicz Z.M., 1979, Metalimnetic gradients and trophic state of lake epilimnia, Mem. Ist. Ital. Idrobiol. 37: 121-143.

Hutorowicz A., Pasztaleniec A., 2014, Phytoplankton metric of ecological status assessment for Polish lakes and its performance along nutrient gradients, Pol. J. Ecol. 62: 525-542.

Kajak Z., 1998, Hydrobiologia - limnologia. Ekosystemy wód śródlądowych. (Hydrobiology - limnology. Inland water ecosystems). PWN, Warszawa, 355 pp. (in Polish).

Korycka A., 1969, Seasonal changes in water chemical composition in seven lakes, Pol. Arch. Hydrobiol. 16: 1-29.

Kudelska D., Soszka H., Cydzik D., 1997, Ekosystemowe podejście do oceny jakości jezior w Polsce. (The ecosystem approach to assessing the quality of lakes in Poland), Ochr. Srod. i Zasob. Natur. 11: 85-92 (in Polish, English summary).

Livingstone D.M., Imboden D.M., 1996, The prediction of oxygen profiles: a plea for a deductive approach, Can. J. Fish. Aquat. Sci. 53(4): 924-932.

Marszelewski W., 2005, Zmiany warunków abiotycznych w jeziorach Polski Północno-Wschodniej (Changes of the abiotic conditions in the lakes of North-East Poland), 
Wydaw. UMK, Toruń, 288 pp. (in Polish, English summary).

[ME] Minister of the Environment, 2013, Rozporządzenie Ministra Środowiska z dnia 21 listopada 2013 r. zmieniające rozporządzenie $\mathrm{w}$ sprawie prowadzenia monitoringu jednolitych części wód powierzchniowych i podziemnych (Regulation of the Minister of the Environment of 21 November 2013 amending the regulation on the monitoring of surface water bodies and groundwater), Journal of Laws, 2013, item 1558.

[ME] Minister of the Environment, 2014, Rozporządzenie MŚ z dnia 22 października 2014 r. w sprawie sposobu klasyfikacji jednolitych części wód powierzchniowych oraz środowiskowych norm jakości dla substancji priorytetowych (Regulation of the Minister of the Environment of 22 October 2014 on the classification of surface water bodies and environmental quality standards for priority substances), Journal of Laws, 2014, item 1482).

[MEEM] Ministére de l'Environement, de l'Énergie et de la Mer, 2016, Guide relatif à l'évaluation de l'état des eaux de surface continentales (cours d'eau, canaux, plans d'eau). Retrieved from http://www.developpement-durable. gouv.fr/IMG/pdf/Guide_REEEESC_mise_a_jour_2016. pdf

Nürnberg G.K., 1995, Quantifying anoxia in lakes, Limnol. Oceanogr. 40(6): 1100-1111.

Olszewski P., Paschalski J., 1959, Wstępna charakterystyka limnologiczna niektórych jezior Pojezierza Mazurskiego (Preliminary limnological characterization of some lakes in the Mazurian Lake District), Zesz. Nauk. WSR Olszt. 4: 1-110 (in Polish, English summary).
Patalas K., 1960, Stosunki termiczne i tlenowe oraz przezroczystość wody w 44 jeziorach okolic Węgorzewa (Thermal and oxygen conditions, and water transparency in 44 lakes of Węgorzewo district), Roczn. Nauk Roln. 77B(1): 105-210 (in Polish, English summary).

Radwan S., Kowalczyk C., Podgórski W., Fall J., 1973, Materiały do hydrochemii Pojezierza ŁęczyńskoWłodawskiego. Część III. Właściwości fizyczne i chemiczne (A contribution to the hydrochemistry of the Łęczna and Włodawa Lake District. Part III: Physical and chemical properties), Ann. UMCS C 28: 97-116 (in Polish, English summary).

[SEPA] Swedish Environmental Protection Agency, 2010, Status, potential and quality requirements for lakes, watercourses, costal and transitional waters. A handbook on how quality requirements in bodies of surface water can be determined and monitored, Handbook 2007 4: 1-65. Retrieved from www.naturvardsverket.se

Vollenweider R.A., Janus L.L., 1982, Statistical models for predicting hypolimnetic oxygen depletion rates, Mem. Ist. Ital. Idrobiol. 40(1): 1-24.

Walker W.W. Jr., 1979, Use of hypolimnetic oxygen depletion rate as a trophic state index for lakes, Water Resour. Res. 15(6): 1463-1470.

Wetzel R.G., 2001, Limnology: Lake and river ecosystems, Academic Press, New York, 1006 pp.

Zachwieja J., 1975, Seasonal and several years' fluctuations of temperature, oxygen content and water visibility in the Mamry Lake complex, Ekol. Pol. 23: 587-601. 